\begin{tabular}{|c|c|}
\hline $\begin{array}{r}\text { Alfred Schaffer } \\
\text { Alfred Schaffer is a Dutch-Aruban } \\
\text { poet, translator and academic who } \\
\text { works as a lecturer at } \\
\text { Stellenbosch University. } \\
\text { Email: aschaffer@sun.ac.za }\end{array}$ & $\begin{array}{l}\text { 'A reflection of a reflection': Notes } \\
\text { on representational and ethical } \\
\text { possibilities in Thomas Mofolo's } \\
\text { Chaka }\end{array}$ \\
\hline
\end{tabular}

\title{
'A reflection of a reflection': Notes on rep- resentational and ethical possibilities in Thomas Mofolo's Chaka
}

In January 2014, I published a Dutch poetry volume Mens Dier Ding (Man Animal Thing) in the Netherlands and Belgium. The book is partly based on research around the historical figure of Chaka, and especially Chaka's fictional representation in three versions of Thomas Mofolo's Chaka, namely the English translation by F. H. Dutton, the later translation by Daniel P. Kunene, and the Afrikaans translation by Chris Swanepoel. In other words, Man Animal Thing is a work of poetic fiction based on (or "inspired by") a work of fiction. This brings with it representational and ethical problems: what is used from which text, what is the tipping point between writing and merely copying, for which type of reader in which context and culture is the new work of fiction meant, and what are the consequences of portraying and imaging a fictional and historical figure? This article tries to highlight several aspects of the creative process of misreading, researching, writing, portraying and transforming in Mens Dier Ding. It explores how "translating" a work of fiction into another work of fiction is at the heart of the continuing conversation that is literature, and may even be a metaphor for postmodern, or better, metamodern literature, which is characterised by an oscillation between both modernism and postmodernism. Keywords: adaptation, anachronism, ethics, metamodernism, poetry, Thomas Mofolo, translation.

1

In the movie Being John Malkovich (1999) by Charlie Kaufmann, someone in an ordinary office building discovers a secret passageway which leads to the brain of the famous American actor John Malkovich. Ultimately John Malkovich himself enters this tunnel, and thus enters his own mind, from the outside. What he sees is something between slapstick and a nightmare.

2

This is the premise of the play Koningin Lear (Queen Lear, 2015) by the Flemish author and playwright Tom Lanoye for Toneelgroep Amsterdam:

In King Lear, Shakespeare tells the story of an ageing king who must share his kingdom among his three daughters, thus precipitating his own ruin and that of his country. In Tom Lanoye's Koningin Lear (Queen Lear), the kingdom becomes an international family company managed by the eponymous "Leading Lady Lear'. From small beginnings, the firm has prospered and grown to unimaginable proportions. 
In Act 1, Leading Lady Lear announces that the company is to be divided up. She demands that her sons take an oath of love and allegiance. The youngest son refuses, with far-reaching consequences. Lanoye paints a portrait of an elderly businesswoman who has lost all sense of reality. She is unable to use her power to solve the very real problems all around her. She is concerned only with popularity and reputation. The piece is unsurpassed in its ability to present the pettiness and powerlessness of a 'ruler' unable to cope with unforeseen events.

3

The example of Being John Malkovich points to the fact that I am about to analyse parts of a book of poetry, Mens Dier Ding (Man Animal Thing), which I have written. Thus I have become my own reader, and enter from the outside, as a reader, into the insides of my own writing. This in many ways can only create havoc because, as we know, the Author, according to Barthes, is a myth, acceptance of which narrows the potentials of meaning in a literary text: "[T]he modern writer (scriptor) is born simultaneously with his text; he is in no way supplied with a being which precedes or transcends his writing, he is in no way the subject of which his book is the predicate; there is no other time than that of the utterance, and every text is eternally written here and now". The reader is the one who is creating the text, expanding it.

The synopsis of Queen Lear given above tells of a form of storytelling as old as human existence, in the sense that it is concerned with adapting, making useful, understandable and specific or close by. When we read a text which is written outside of our own socio-economic, historical or political context or time zone, we often read this text in a historical and sociological way rather than experiencing it as a piece of art. If we want not only to read such a text, but own it as well, a particular narrative is then often adapted or transformed with the help of one specific literary tool: the anachronism.

4

Anachronism, deliberate or unintentional, reveals hidden myths and assumptions of the source and of its successor, in an ethical as well as in an aesthetic way. It heightens or stresses the notion of artificiality, and at the same time makes the adaptation or "translation" recognisable because of the estranging elements. If we look once more at the example of the premise of Queen Lear, we notice all kinds of hidden meanings being produced by anachronisms. Suddenly we become aware of feminism and the preconceived idea that power is linked to maleness as well as the demands of the corporate world of business. We see that King Lear may be a drama with a universal theme, but that the version by Lanoye makes it strangely local. It tells us that monarchical leadership might be an outdated system, but that the economic powerhouses and private businesses of our present day are more or less run as monarchies. 
Queen Lear would not be an anachronistic piece of art if it was not a creative adaptation of the Shakespeare text. In the case of Man Animal Thing, one could also speak of a creative adaptation, which is different from being merely "inspired by". The adaptation keeps the original source firmly as its guide, a story inspired by another story, using parts of the original content or plotline and only certain symbolic gestures made by the original. Man Animal Thing was published in 2014 and "based" not only on the so-called historical facts of Chaka's life, but more specifically it is in parts a rewriting, an adaptation of the novel Chaka by Thomas Mofolo.

Chaka was written in Sesotho in the first decade of the twentieth century, but only first published some fifteen years later. After being immediately translated into English by F. H. Dutton, it was again translated and published in 1981 by Daniel P. Kunene. The Afrikaans translation by Chris Swanepoel was first published in 1974.

As far as Mofolo was concerned, there was never a doubt about his intentions relating to the facts around Chaka. In his introduction Kunene (xv) quotes Mofolo:

I believe that errors of this kind [concerning the accuracy of certain historical facts around the establishment of the Shangana nation] are very many in the book Chaka; but I am not very concerned about them because I am not writing history, I am writing a tale, or should I say I am writing what actually happened, but to which a great deal has been added, and from which a great deal has been removed, so that much has been left out, and much has been written that did not actually happen, with the aim solely of fulfilling my purpose in writing this book.

Kunene (xv) asks himself, just as other readers probably have done over the years: what could that "purpose" be? The answer may be found in the title of an earlier Mofolo manuscript (now lost) probably dating from 1908 and known best by its French title: "L' Ange déchu" — "The fallen angel" (Kunene xii). This title bears on Chaka if we assume that Mofolo initially wanted to write a tragic story in which the main character could be mystified and at the same time humanised, by making major alterations to an oral story such as inventing characters such as Isanusi, Ndlebe and Malunga who enact Chaka's inner motives or thoughts. (I am aware that here I am diverging from Barthes's view of the author as myth.)

It seems that Mofolo sees in Chaka a prototype of our modern sense of good and evil. In the vision of Alain Badiou, in Ethics: An Essay on the Understanding of Evil, Mofolo's Chaka would be a man whom we cannot simply judge as "good" or "evil". Badiou (91) agrees with Nietzches's view that the so-called human animal is in essence not guilty, but he states that any form of life, rather than being past Good and Evil (Nietzches' infamous notion of the Übermensch), precedes Good and Evil. Numbed by an immanent fracture or disaster, one sees ones chances at survival diminish: the reaction following this fracture is crucial. We see in the more or less factual and historical 
narrative about Chaka how Mofolo turns him, no matter how evil he turns out to be, into a victim of Circumstance and the Other. This does not make him more, or even less, sympathetic as a protagonist than he would otherwise have been, but it does turn him into a tragic figure and thus an ordinary human being as well.

A human being who is able to fall in love. And this is indeed "the most notable deviation from history", as Kunene writes in his introduction: the invention of "Noliwa". Kunene (xviii) sees her as:

the instrument for bringing to the surface the "last spark of humanity still remaining in him", namely his human tenderness and his capability of loving. And there is no question about the genuineness of this love which makes Chaka dance for joy, and whose kindling and nurturing by Ndlebe is in sharp contrast to its ruthless sabotage and banishment by Isanusi at the time when it is at its highest peak. Chaka's murder of Noliwa who is now pregnant with his child, is another artistic high watermark for Mofolo. It is symbolic of the murder of both love and life in one swift stroke.

Mofolo's version or translation of the mythical narrative is therefore, as it were, a reflection of a reflection, and is owned by no one.

\section{6}

Man Animal Thing may be written in this day and age, but the template on which it is based is timeless, as the theme of the Fallen Angel demonstrates so well. The Dutch "version" of Chaka's story in Man Animal Thing was informed by many intertexts like Femmes de Dictateur (2012) by Diane Ducret, The Washing of the Spears (1998, second edition) by Donald Morris, Shaka Zulu (1985) by E. A. Ritter, and the study of Chaka within the context of the psychology of tyrannical power by Manfred Kets de Vries (2004). But I was also inspired by works such as Anne Carson's Red Doc> (2013), The Sovjet UFO Dossiers (1998), the song "Heroes" by David Bowie, the second Batmanmovie The Dark Knight and the movie Apocalypse Now, Ovid's Metamorphoses, the trials of the South African Paralympic athlete Oscar Pistorius, and the interviews with the Dutch student Tania Nijmeijer who joined the militant Revolutionary Armed Forces of Colombia, also known as the FARC.

As pointed out by Mofolo himself, his Chaka is a narrative with many gaps, omissions and additions-in a very deliberate sense (Chaka xv). Mofolo's text itself is-in the theory of scholars such as Julia Kristeva—constantly absorbing, ignoring, anticipating and reacting to other texts, texts in the sense of "versions of history", "specific cultural influences" (van Dijk, de Pourcq and de Strycker 25-30).

7

Man Animal Thing can be seen as a fragmented epic poem, consisting of various formal and lyrical elements, in the tradition of other modern, scattered epic poems 
based on well-known myths or historical figures or happenings, such as Der Untergang der Titanic (1978) by Hans Magnus Enzensberger, Lady Anne (1989) by Antjie Krog, Autobiography of Red (1998) by Anne Carson or The Collected Works of Billy the Kid (1970) by Michael Ondaatje.

In Man Animal Thing there are the so-called daydreams of Chaka (or "Sjaka", as he is consequently named in the Dutch text), short poems told in the first person with a vulnerable and estranging voice. Then there are the poems in which Chaka's mother expresses her concerns about her son and shows her unconditional love. There is a live broadcast of the court case against Chaka at the height of his powers, with live tweets and a PowerPoint presentation. There is a game show with Chaka as an unwilling (and of course the only) candidate-unwilling because he has fallen asleep in front of the television and is thus unable to walk out, until he is finally woken by his servants. And then there are the long narratives in between, which are more or less the anachronistic adaptations based on the different chapters in Mofolo's Chaka.

These reworkings are placed between the other poems, and are based more on the Chris Swanepoel translation than on the translation by Kunene. Kunene (xiv) writes in his Introduction: "Unfortunately the translator, Chris Swanepoel, has marred an otherwise good translation by leaving out portions of the original without any explanation whatsoever. Some of these omissions are quite extensive". Nonetheless there is much to say for Swanepoel's version, which is a direct translation from the original Sesotho, has pace, and is lyrical and precise in language. If we compare a random fragment from Swanepoel's translation with the same fragment of Kunene's version, it is clear that the general content is more or less the same in both versions, but the style differs quite clearly. If we take the introduction of Noliwa in chapter twelve, Kunene translates:

Among all his sisters, the one whom Dingiswayo loved the most was the one who came last out of his mother's intestines, the last-born. She looked very much like the girl after whom Dingiswayo himself was born, who saved him the day he and Tana, his older brother, were in danger of their lives. Those two girls resembled each other like twins, to the very way they talked. Therefore Dingiswayo loved this surviving one more than all his other sisters by far, not so much because she was the child of her mother's womb, but because in this one's face he saw the face of his favourite sister who had died. Her eyes, her cheeks, her ears, her voice, her figure, her ways-all these were exactly like those of the one who had died, who had sacrificed herself for him at a critical time when death stared him in the face. Her name was Noliwa, and she was amazingly beautiful, and crowned it all by having a kind, compassionate heart, which was always well disposed towards other people. (Mofolo, Chaka 71)

The same introduction in the Afrikaans translation by Swanepoel, goes as follows: Onder die susters van Dingiswayo was die een wat hy die liefste gehad het, sy moeder se laaste kind. Sy het baie ooreengekom met 'n suster wat net ouer as hy was en wat 
hom gered het die dag toe hy saam met sy ouer broer, Tana, gesterf het. Hierdie twee kinders het soos ' $n$ tweeling ooreengekom, ook in hulle manier van praat. Daarom was Dingiswayo vir haar liewer as al die ander-nie soseer omdat sy sy moeder se laaste was nie, maar omdat haar gesig was soos dié van sy suster wat dood is. Haar oё, wange, stem, maniere, alles was soos die een wat dood is, wat hom uit die ellende, uit die dood verlos het. Haar naam was Noliwa. Sy was wonderlik mooi, vervolmaak deur haar wit, vriendelike, sagmoedige hart. (Mofolo, Tjhaka 54) ${ }^{1}$

The length of the sentences is different, and the rhythm in both versions differs as well. It seems as if the version by Kunene is a more literal translation ("intestines"), while there is certainly a very natural flow in Swanepoel's wonderful version; as if the Afrikaans version is less concerned about making sure that the uninformed reader doesn't miss anything "vital", and more involved with producing a great literary equivalent.

Both versions, the one by Swanepoel as well as the one by Kunene, consist of 26 chapters; for Man Animal Thing almost each chapter was reworked into a separate poetic narrative. Some small chapters were taken together and subsequently "translated" or transposed.

\section{8}

In chapter twelve of Mofolo's Chaka the reader is introduced to the character of Noliwa. The Dutch poem works with Chaka as an intertext, but also hyper-corrects the notion or unofficial knowledge that Chaka might have been homosexual, or that he was not interested in sex or love in a "romantic" way. In the Dutch poem, Noliwa is thus reduced again to merely a projection, or real hallucination, and named only "N", which probably does not ring a bell with most Dutch readers- $\mathrm{N}$ does fall pregnant later on in the Dutch poem. The poem's version of Mofolo's chapter twelve now goes as follows:

Sjaka vindt uiteindelijk de liefde van zijn leven

in een modetijdschrift van zijn moeder.

Die ogen en die kleine kin, die jukbeenderen!

Noemt haar N, hoe moet hij haar omschrijven.

Als een wandeling bij avond na een feeërieke film.

Als een rit in zijn aftandse kever

tussen rotsachtig gebergte, hij slingert langs een rimpelloze beek

en plotseling breekt de zon door

breekt het zonlicht door de ruimte, diep beneden

ligt het dal waar hij zal blijven slapen.

$\mathrm{N}$ ! Als een abrupte smaak die losbarst in je mond

een stortbui in het hartje van de zomer. 
Verslavend als een voetbalspelletje.

Sleetse beeldspraak klaagt zijn biograaf maar ach

zolang het werkt, denkt Sjaka.

Die zo argeloos vermorzelt maar niet dansen kan.

Die steeds weer op de tenen van zijn partner trapt.

Heeft geen idee hoe hij een drankje aan moet bieden

hoe je met je hele mond moet zoenen.

Als kleine jongen werd hij met de liefde vaak gepest.

'Dikke Babette gaat met Sjaka naar bed'

en 'Sjaka = Nerd' stond met koeienletters

op de zijmuur van de buurtwinkel geschreven.

Giftig rende hij naar huis, verborg zich

op zijn kamertje en kwam er dagenlang niet uit.

Geconcentreerd slijpt hij de punt bij van zijn speer

en vraagt zich af of $\mathrm{N}$ van zijn bestaan afweet.

Of hij haar in haar dromen uit de vlammen redt

en of zij starend naar zijn foto wat parfum

tussen haar borsten spuit, het eten aan laat branden

met make-up haar oneffenheden wegpoetst

terwijl ze 'They can't take that away from me' neuriet.

Radeloos van ongeleid verlangen

begeeft hij zich zo'n vier keer in de week

richting de roodverlichte achterstraten van het dorp.

Dan blijft hij weg tot hij geen cent meer heeft.

Ver na middernacht zwalkt hij nog over straat.

In een leven van minuut tot minuut

op weg naar meer en steeds meer leven ${ }^{2}$

What is left here of the "original" text? The elatedness and the ecstasy as projected onto Chaka can be found in the Dutch poem as well as in chapter twelve in the novel:

"What are you saying, Ndlebe? Are you telling me that 'that very one' loves me more than I love her? Which very one?" "The very one who just came in here. Noliwa herself." Chaka once again began to walk around like someone dancing the motheke-theke dance, and then when he cooled off again after a while he sat down and listened to Ndlebe's story. (Mofolo, Chaka 75)

The clichéd and romantic notion of the ideal love that is out of reach is also present. Not present in Mofolo's version are the visits to the red light district of Chaka's time, 
the insinuation of paid sex which could function as metaphor for Chaka's omnipresent and deadly desire.

In Man Animal Thing $\mathrm{N}$ will turn out to be unreachable throughout, which is demonstrated by another poem, one which is not based on a specific chapter in Mofolo's Chaka, but referring to the conclusion that has to be drawn after reading Mofolo's novel, namely that a human being, so hungry for power, perhaps is not capable of unconditional love, and that $\mathrm{N}$ is only a projection, a literary tool:

Sjaka's korte flirt met romantiek

Op een dag verscheen hij als verschijning aan haar deur.

Het moet zijn eerste en zijn laatste poging zijn geweest.

Bosje bloemen in de hand, wat rozen en chrysanten

schone rook blies uit de rookmachine achter hem

en bungelend aan touwen het hell

bewust apolitiek en stralend.

Het had een cent gekost en flink wat logistiek

en bloedvergieten, maar zijn voorpret

richtte het vizier op het spektakel in haar bed.

Had men hem wat dan ook gefliktop dat moment, standvastig was hij blijven staan.

Klopte aan en nog een keer en nog maar eens.

Wat bleek na enig overleg

hij stond voor het verkeerde huis!

Onderdanen gleden lacherig en ongelovig

uit de bomen, ramen werden weer gesloten

ook de dames van de drumband maakten rechtsomkeert.

Geruisloos werd hij weggeleid

een afgeleefde aak in een immens kanaal

en men vergat die hele zaak opdat dit nooit

en nooit weer zou gebeuren. ${ }^{3}$

9

It seems as if the legend of Chaka is wrapped in a line of several literary misreadings and appropriations. It starts with the Mofolo novel itself. After his debut in 1907, Moeti oa bochabela (Traveller to the East), the first novel in Southern Sotho, Mofolo published Pitseng (1910). As was the case with his debut, the influences of Christian beliefs are evident in Pitseng. Although Mofolo was hailed as a talent from the start, his novel Chaka is really seen as a masterpiece.

The reader must keep in mind though that this novel about the Zulu conqueror is a fictional work, an adaptation, an appropriation. And a very important breakaway from previous work, as Krog (12) argues:

By choosing Shaka as theme, Thomas Mofolo made a radical break towards a time 
before the missionaries and outside the Basotho community. One suspects that he was searching for a theme in which he could have more freedom of movement to express his talent and imagination outside the scope of the missionaries and their conversion message in Lesotho. By using the figure of Shaka, Mofolo found the ideal lens to explore an indigenous black moral framework, unaffected by Christianity. Already by suggesting that a moral framework existed outside Christianity, and that he refused to judge his main character through Christian spectacles, was in itself confrontational and probably explains the unexplained publication route of the manuscript. The publication of Chaka was held back by fifteen years during which letters and remarks flew among the missionaries, and between the missionaries and Europe as well. Some of them requested that the manuscript not be serialised in the local newspaper, while others believed that the publication would tumble the Basotho back into witchery and magic. ${ }^{4}$

In other words, to appropriate a narrative can be a minefield, a dangerous and difficult ethical process. In the case of Mofolo, his background even added more controversy: "The late publication of the manuscript created even more controversy, because suddenly Zulu speakers were also angry: what did a Basotho know about a Zulu? How dare a Basotho judge the founder king of the Zulu?" (Krog 12). ${ }^{5}$

It can be argued that many misreadings take place between Chaka and Man Animal Thing too. One of them has to do with the literary form: from the twentieth-century prose in the Mofolo novel, to twenty-first century poetry. The concept of the tragic figure falling deeper into the heart of his own darkness is also visible in Man Animal Thing. What is new in the latter text is the element of irony, as is seen throughout, sometimes explicitly, as with the game show or the court case with live tweets, sometimes more implicit, in lines such as "It had cost a pretty penny, some serious logistics / and bloodshed, but his anticipatory pleasure / set its sights on the spectacle in her bed". Irony is a serious matter, and a dangerous one in the sense that it can easily ridicule, and in the context of the Chaka story can underplay the elements of history, war, violence and culture. The irony was part of the strategy to underscore the seriousness of Chaka's daydreams, his innermost fears, longings, desperation, in other words his humanity.

Probably the most serious misreading, and the one with the most ethical pitfalls, is the one between a South(ern) African and a Dutch text. Chaka becomes "Sjaka" in Dutch, suggesting the typical Dutch boys-name "Sjaak". The clash of Dutch with "African" culture was a deliberate one, and the anachronisms all chosen from European (or "Western", popular) culture as well. In her article Krog (15) quotes Degenaar, about the modern Western myth of personal morality:

Eurocentric culture is based on twenty five centuries of Greek culture (philosophy),

Roman culture (jurisprudence) and Judeo-Christian cultures (religion). It places high priority on individuality and reason and is inclined to presuppose that European values could be applied universally. The tension between the particular and the universal is 
assumed to be dissolved, since the particular is supposed to be universal. Afrocentric culture, on the other hand, reflects the cultural values, symbolic forms and achievements of Africa which claim recognition and respect for being the cradle of mankind-both physically and spiritually. With its rich source of oral and other literature, indigenous art works, plurality of religions and languages, it places the emphasis on communality and a view of a human being, which presupposes interpersonal relationships as expressed in umuntu ngumuntu ngabantu, which means a person is a person through other persons.

One of the main traps is to fall into the cliché of the old opposition between "Europe" and "Africa", and the danger of making stereotypes of both narrative lines. As a literary mechanism, is the adaptation of an existing myth or narrative not bordering on colonialism, or neo-colonialism? As Mbembe (177) argues:

First, one takes anecdotes, fragments of the real world, scattered and disconnected things, things one has not actually witnessed but only heard from a chain of intermediaries. Then one eliminates all references to time. All the variety of the stories is ironed out; all local reference is removed. From these remains of the actual and of the froth of rumor, one makes furtive sketches, scenes rearranged as one likes, pictures full of movement - in short, a dramatic story in which words and images, in the final analysis, amount to very little. When not commenting on buffoonery, unbridled enjoyment, and the urge to destroy, they are telling of catastrophe, convulsions, disaster already happened or about to happen—of breakdown, instant terror. It matters little that the words do not relate to any precise event, provided that they preserve, for the phenomena allegedly being described, stark immediacy, and testify to the primacy of sensation and the utterness of the region's disorder.

Writing, or rather adapting, could thus become grotesque:

From this angle, to colonise is to put to work the two-faceted movement of destroying and creating, creating by destroying, creating destruction and destroying the creation, creating to create, and destroying to destroy. To this extent, to colonise is, par excellence, a gratuitous act. To colonise is also to deploy a subjectivity freed of any limit, a subjectivity seeing itself as absolute but which, to experience that absolute, must constantly reveal it to itself by creating, destroying, and desiring the thing and the animal that it has previously summoned into existence. From the standpoint of the conqueror, the colony is a world of limitless subjectivity. In this, the act of colonising resembles a miracle. (Mbembe 189)

Following the footsteps of Mofolo's Chaka was of the highest importance in Man Animal Thing, to keep with the initial outlines and settings of Mofolo's story, to avoid portraying Chaka as only evil, or only heroic, only an individual victimised by his 
own circumstances, and at the same time break away from seeing Chaka as a single rounded character instead of a construction of rounded characters, influences and moral (mis)behaviour.

In the end, the intentions of a writer are of no concern to the reader; but it is here where the tool of anachronism enters-highlighting the artificiality of the new text while allowing the writer to "own" the old text, without ignoring moral boundaries. Because of the inherent ironical aspects of the anachronism as a literary tool, one can fence off, up to a certain point, stereotyping and type casting, as it were, in a daydream like the following:

Dag(droom) \#9.377

Ik was misschien een uurtje thuis

toen sloop ik weer naar buiten.

Niet lang meer of de zon zou ondergaan

ik liep de weg op naar het bos achter de treinbaan

en de voetbalvelden met mijn zelfgemaakte speer.

De punt een ijselijk gekrijs.

Er zou een hond zijn losgebroken

van een zeldzaam ras, gitzwart als een donderpreek

het schuim dat op zijn kaken stond.

Blaffend om het donker voor te blijven

flitste ik mijn schaduw achterna tussen de stammen door

tot een massief gordijn werd weggerukt.

Daar lag iets, half verstopt onder wat bladeren en zand.

Ik hief mijn speer, deed een stap naar voren bleef zo staan.

Alsof ik plotseling geen recht van spreken had-

mijn T-shirt plakte aan mijn bovenlijf

het prisma van mijn huid was als een flakkerende droom.

Even gaf ik licht

toen werd ik uitgedoofd. ${ }^{6}$

Anachronism also made it possible to elaborate on the discourse of black versus white, local versus foreign, and to turn Chaka into an asylum seeker in the Netherlands, lost in a Western context where foreigners are often branded "illegal" (depending on their economic, racial, religious and geographical background) despite being leaders in their own context, "despotic" leaders even. The irony would then be that everyone is treated in the same bureaucratic, racist manner when being a non-European refugee, so much so that it does not even matter how bad your credentials are. The aim was to put a black man in a modern work of Dutch (Western) poetry, in his own right, judged only on the base of his own character and deeds, without references to the racist ideas and colonial clichés of the black man himself, or "negro": 
[A] rather haphazardly developed set of almost naked organs: fuzzy hair, flat nose, thick lips, face covered with cuts. He/she stinks. Every time the Negro says something, he/she gesticulates wildly. Crushed by age-old atavism, he/she is unable to control his/ her instincts, and is quite incapable of thinking for him/herself or knowing right from wrong. His/her gestures and attitudes are quite primitive. (Mbembe 180)

10

In many reviews Man Animal Thing was indeed seen as an analysis of a fallen angel, just like the title of the lost version of Mofolo's third manuscript a century ago, about a man undergoing the transformation from a human being, into an animal, only to end up as a "thing". One critic read in it the story of a man who is slowly losing autonomy over himself, because of the different characters, situations, viewpoints and narratives trying to own him. That same critic said: "Google has contributed a lot to my appreciation of the book. Before reading this book the South African statesman Chaka Zulu was hardly known to me" (Ham).

This stresses once more the necessity of the anachronism, and the ambivalent position of this particular text which was conceived by a Sesotho writer, is firmly rooted in a South(ern) African context but is now bound to be read in a Dutch context. Thus the text must reflect on this position, acknowledge it, but also forget its position at the same time, to prevent itself from falling into the trap of relativism. In this context, this postmodern or late-postmodern poem Man Animal Thing may also be referring to another philosophical way of framing known as "metamodernism":

Whereas postmodernism was characterised by deconstruction, irony, pastiche, relativism, nihilism, and the rejection of grand narratives (to caricature it somewhat), the discourse surrounding metamodernism engages with the resurgence of sincerity, hope, romanticism, affect, and the potential for grand narratives and universal truths, whilst not forfeiting all that we've learnt from postmodernism.

Thus, rather than simply signalling a return to naïve modernist ideological positions, metamodernism considers that our era is characterised by an oscillation between aspects of both modernism and postmodernism. (Turner)

No vision is clear or precise, and it is this tension that creates "new" works and is the driving force behind much modern art and literature. Man Animal Thing owes everything to Thomas Mofolo's Chaka, and is at the same time a universe away from that text. Or to quote Perloff (23):

Appropriation, citation, copying, reproduction - these have been central to the visual arts for decades [...] In the poetry world, however, the demand for original expression dies hard: we expect our poets to produce words, phrases, images, and ironic locutions that we have never heard before. Not words, but My word [...] But as the various avant-garde movements demonstrated as early as the 1910s [...] there are other ways of Making It New. 
When John Malkovich enters his own head in Being John Malkovich, he more or less sees pictures of himself, appearing in pictures of himself. This is something different from a "reflection of a reflection", which is ideologically loaded because it is the projection of the viewer; that is how a "translation" of a controversial figure such as Chaka will mostly turn out to be, when jumping from one text to another; a vision on human existence, because a mere objective representation of it, is-at least in our days-impossible.

\section{Notes}

1. Problems around reliability of the several translations of Chaka are clearly visible here, where the Afrikaans uses a word ("wit" - "white") that is absent in Kunene's version.

2. In the translation of the Dutch by Michele Hutchinson it reads: Shaka finally finds the love of his life / in one of his mother's fashion magazines. / Those eyes and that small chin, those cheekbones! / Calls her N, how should he describe her? / Like an evening stroll after a magical film / like a drive in a dilapidated Beetle/ between rocky mountains, he meanders along a glassy stream/and suddenly the sun breaks through / the sunlight breaks through the air, far below / is the valley where he will spend the night. / N! Like an abrupt taste that explodes in your mouth / heavy rain at the height of summer. / As addictive as a football game. / His biographer complains of hackneyed imagery, never mind / as long as it works, Shaka thinks. / Who crushes so guilelessly but cannot dance. /Who keeps treading on his partner's toes. / Has no idea how to offer a drink / how to kiss with your whole mouth. / As a young boy he was often teased about love. / "Fat Babette is shagging Shaka" / and "Shaka = Nerd" in giant letters / on the side wall of the corner shop. / Bitter, he ran home, hid himself away / in his bedroom and didn't come out for days. // He concentrates on sharpening the point of his spear/and wonders whether $\mathrm{N}$ knows that he exists. / Whether in her dreams he rescues her from the flames / and whether she sprays a little perfume between her breasts / while looking at his photo, leaves the dinner to burn / disguises her imperfections with make-up / while humming "They can't take that away from me". / About four times a week and / crazy with longing he heads towards / the red-lit backstreets of the village. / He stays there until he hasn't a cent left. / Long after midnight he's still roaming the streets. / Living from minute to minute on his way to more and still more life.

3. Shaka's brief flirtation with romance: One day he appeared at her door like an apparition. / It must have been his first and last attempt. / Bunch of flowers in his hand, some roses and chrysanths / clean smoke blowing out of the smoke machine behind him / and the universe dangling on ropes consciously apolitical and shining. / It had cost a pretty penny, some serious logistics / and bloodshed, but his anticipatory pleasure / set its sights on the spectacle in her bed. / If anyone had tried to pull one over on him / at that moment, he would have stood his ground. / Knocked and then again and then again. /After some discussion it turned out/ he was at the wrong house! / Laughing in disbelief, locals slid / down from the trees, windows were closed again / even the ladies from the drum band made an about turn. / He was led off silently / a decrepit barge in an immense canal / and people forgot about the whole business so that it / would never happen again.

4. “Deur Shaka as tema te kies, het Thomas Mofolo 'n radikale breuk gemaak na 'n tydperk voor die sendelinge en buite die Basotho-gemeenskap. Mens vermoed dat hy op soek was na'n tema waarin hy meer bewegingsvryheid vir die ontplooiing van sy talent en verbeelding kon hê buite die bereik van die sendelinge en hulle bekeringsboodskap in Lesotho. Deur die figuur van Shaka te gebruik, het Mofolo die ideale lens gevind om ' $n$ inheemse swart morele raamwerk, onaangetas deur kerstening te ondersoek. Net die feit dat Mofolo kon suggereer dat'n morele raamwerk buite om Christenskap bestaan het, en dat hy in die teks self weier om ooit sy hoofkarakter deur' $n$ Christelike bril te oordeel, was alreeds konfronterend en verklaar waarskynlik die onuitgeklaarde publikasieroete van die boek. Shaka se publikasie is met byna vyftien jaar vertraag waarin briewe en opmerkings heen en weer tussen die sendelinge onder mekaar, asook die sendelinge en Europa gevlieg het. Van hulle het versoek dat die teks nie as vervolgverhaal in die Sesotho-koerant geplaas mag word nie, terwyl ander geglo het dat die publikasie van 'n boek oor die verhaal in elk geval die Basotho sal terugdompel in heksery en toordery". 
5. "Die uiteindelike publikasie van die boek was in nog wyer omstredenheid gehul, want skielik was die Zulu-sprekendes ook woedend: wat weet'n Basotho van 'n Zulu? Hoe durf'n Basotho'n oordeel vel oor die fondamentlegger van die Zulu?"

6. Day(dream) \#9.377: I'd been home maybe an hour / when I slipped out again. / Not long before the sun would set / I walked up the road to the woods behind the railway line / and the football pitches, carrying my homemade spear. / Its point a dreadful screech. / They said a dog had got out/ some rare breed, jet black as a sermon, / the froth that was on its jaws. / Barking to stay ahead of the darkness / I flitted after my shadow between the trees / until a solid curtain was ripped away. / Something was there, half-buried under a few leaves and sand. / I raised my spear, took a step forwards and froze. / As though I had suddenly forfeited the right to speak - / my T-shirt stuck to my body / the prism of my skin was like a flickering dream / for a short time I emitted light / and then I was put out.

\section{Works Cited}

Badiou, Alain. De Ethiek. Essay over het Besef van het Kwaad. Trans. Rokus Hofstede. Utrecht: Uitgeverij IJzer, 2007.

Barthes, Roland. "The Death of the Author." Aspen 5 \& 6 The Minimal Issue (1967). 1 Mar 2015. <http:// www.ubu.com/aspen/aspen5and6/threeEssays.html\#barthes $>$.

Carson, Anne. Autobiography of Red. Toronto: Alfred A. Knopf, 1998. , Red Doc >. London: Jonathan Cape, 2013.

De Vries, Manfred F. R. Kets. De Geest van Despotisme. Shaka Zoeloe en de Psychologie van Tirannieke Macht. Amsterdam: Uitgeverij Nieuwezijds, 2004.

Dijk, Yra van, Maarten de Pourcq and Carl de Strycker. Ed. Draden in het Donker. Intertekstualiteit in Theorie en Praktijk. Nijmegen: Van Tilt, 2013.

Ducret, Diane. Femmes de Dictateur. Paris: Perrin, 2012.

Enzensberger, Hans Magnus. Der Untergang der Titanic. Frankfurt am Main: Suhrkamp, 1978.

Ham, Laurens. "Harde Feiten. Over Mens Dier Ding van Alfred Schaffer." De Reactor. 5 Des. 2014. 1 Mar 2015. <http://www.dereactor.org/home/detail/harde_feiten/>.

Krog, Antjie. Lady Anne. Cape Town: Human \& Rousseau, 1989.

"Die Verkleurmannetjie(s) op Shaka: 'n Vergelyking tussen D. J. Opperman en Thomas Mofolo." Tydskrif vir Letterkunde 47.2 (2010): 5-18.

Kunene, Daniel P. “Introduction.” Thomas Mofolo. Chaka. Trans. Daniel P. Kunene. Johannesburg: Heinemann, 1981. iv-xxiii.

Mbembe, Achille. On the Postcolony. Johannesburg: Wits University Press, 2015 [2001].

Mofolo, Thomas. Chaka. Trans. Daniel P. Kunene. Johannesburg: Heinemann, 1981.

. Tjhaka. Trans. Chris Swanepoel. Cape Town: Tafelberg, 1974.

Morris, Donald. The Washing of the Spears. Boston, MA: Da Capo Press, 1998 [1965].

Ondaatje, Michael. The Collected Works of Billy the Kid. London: Vintage, 1970.

Perloff, Marjorie. Unoriginal Genius: Poetry by Other Means in the New Century. London, Chicago: The U of Chicago P, 2010

Ritter, E. A. Shaka Zulu. London: Penguin, 1985.

Schaffer, Alfred. Mens Dier Ding. Amsterdam: De Bezige Bij, 2014.

"Day(dream) \# 9.377". 1 Mar 2015. <http://www.poetryinternationalweb.net/pi/site/poem/ item/24545/auto/0/DAYDREAM-9377>.

. "Shaka's brief flirtation with romance." 1 Mar 2015. < http://www.poetryinternationalweb.net/pi/ site/poem/item/24549/auto/0/SHAKAS-BRIEF-FLIRTATION-WITH-ROMANCE>.

"Shaka finally finds the love of his life." 1 Mar 2015. < http://www.poetryinternationalweb.net/pi/ site/poem/item/24547/auto/0/SHAKA-FINALLY-FINDS-THE-LOVE-OF-HIS-LIFE>.

Toneelgroep Amsterdam. "Queen Lear." 8 Mar 2015. 1 May 2015. < http://tga.nl/en/productions/koninglear>.

Turner, Luke. “Metamodernism: A Brief Introduction.” 12 Jan 2015. 12 Dec 2015. < http://www.metamodernism.com/2015/01/12/metamodernism-a-brief-introduction/>. 